\section{An in vitro evaluation of the effects of different acidic beverages on the surface hardness of restorative materials}

\section{Farklı asidik içeceklerin restoratif materyallerin yüzey sertliklerine olan etkilerinin in-vitro olarak değerlendirilmesi}

\section{Asist. Prof.Dr. Ebru Uslu Cender}

Ordu University, Faculty of Dentistry Department of Restorative Dentistry, Ordu

Assoc. Prof. Dr. Eda Güler

19 Mayıs University, Faculty of Dentistry Department of Restorative Dentistry, Samsun

Received: 11 March 2017

Accepted: : 4 September 2017

doi: 10.5505/yeditepe.2017. 71473

\section{Corresponding author:}

Asist. Prof.Dr. Ebru Uslu Cender

Ordu University, Faculty of Dentistry Department of Restorative Dentistry, Ordu 52100, ORDU

Tel: $04522121286-5008$

Fax: +90 4522121289

E-mail: ecender@hotmail.com

\section{SUMMARY}

Aim: The aim of this study was to examine the effects of different acidic beverages on the surface hardness of restorative materials which are frequently used in clinical practices.

Materials and Methods: In this study, cola, sour cherry juice, apple juice, energy drink and orange juice were used as acidic beverages while two composite resins (Filtek Silorane, Filtek Z-550), one flowable composite (Filtek Ultimate Flowable), one compomer (Dyract Extra) and one resin modified glass ionomer (Fuji II LC) served as restorative materials to be tested. After measuring the initial surface hardness of the samples with Barcol surface hardness tester, each sample was put into acidic beverage for five seconds after which they were placed in artificial saliva for five seconds. This cycle was repeated ten times daily for one month. The control group was stored in the artificial saliva without any exposure to this cycle. At the end of the one-month-period, surface hardness of the restorative materials were measured again.

Statistical analysis used: "Repeated Measures Analysis of Variance" and "Tukey's Multiple Range Test" were used for statistical analysis.

Results: The restorative materials were affected by the acidic beverages. The liquids used in the study, except the artificial saliva, had statistically similar effects on the surface hardness values of the materials used $(p<0.05)$.

Conclusion: In conclusion, the beverages used in this study affected the surface hardness of the restorative materials investigated differently.

Keywords: Surface Hardness, Acidic Beverages, Resin Composite, Compomer, Silorane

\section{ÖZET}

Amaç: Bu çalışmanın amacl; farklı asidik içeceklerin kliniklerimizde sıkça kullanılan restoratif materyallerin yüzey sertlikleri üzerine etkilerini incelemektir.

Gereç ve Yöntem: Bu çalıșmada asidik içecekler olarak kola, vişne suyu, elma suyu, enerji içeceği ve portakal suyu; restoratif materyal olarak ise iki adet kompozit rezin (Filtek Silorane, Filtek Z-550), bir adet akışkan kompozit (Filtek Ultimate Flowable), bir adet kompomer (Dyract Extra) ve bir adet rezin modifiye cam iyonomer (Fuji II LC) kullanıldı. Başlangıç yüzey sertlik değerleri Barcol yüzey sertlik ölçüm metodu ile ölçüldükten sonra her bir örnek 1 ay boyunca toplam 10 döngü olmak üzere; 5 sn asidik içecek, 5 sn yapay tükürükte bekletildi. Kontrol grubu, örnekler döngüye tabi tutulmaksızın yapay tükürük içerisinde saklandı. 1 ayın sonunda restoratif materyallerin yüzey sertlikleri tekrar ölçüldü. İstatistiksel değerlendirme "Tekrarlanan Ölçümlü Varyans Analizi" ve "Tukey çoklu karşılaştırma testi" ile yapıldı.

Bulgular: Restoratif materyaller asidik içecekten etkilenmiștir. Deneyde kullanılan sıvılardan yapay tükürük dışındaki sıvılar, kullanılan materyallerin yüzey sertlik değerleri üzerinde 
istatistiksel olarak benzer etki göstermiştir $(p<0,05)$.

Sonuç: Sonuç olarak, bu çalışmada kullanılan içecekler, incelenen restoratif materyallerin yüzey sertliklerini farklı şekillerde etkilemişlerdir.

Anahtar Kelimeler: Yüzey sertliği, asidik içecekler, kompozit rezin, kompomer, Silorane

\section{INTRODUCTION}

One of the most significant contributions to dental technology has been the introduction of adhesive dentistry. ${ }^{1}$ The composition of the resin-based composites have changed significantly since their introduction to the market. One of the most significant of these changes is the reduction of the filler size and the increase in the amount of it, which, in turn, enabled the production of materials with higher wear resistance and easier polishability. ${ }^{2,3}$ Nanohybrid composites were produced by adding particles of nano size to microhybrid composite resins ${ }^{4}$ In addition to the ad $\neg$ vantages of nano fill and/or nanohybrid resin composites such as strength, low wear, and polishability, these mate $\neg$ rials generally have different shades, allowing the natural dental tissue reproduction in an efficient way with the stratification technique. ${ }^{1}$

One of the disadvantages of composite resins is polymerization shrinkage ${ }^{5}$ "Silorane" monomer, whose name was derived from its chemical components, namely, siloxane and oxirane, was developed to overcome this drawback. 4,6,7 Silorane based composite resin, which is argued to be more resistant to saliva, water and chemicals in the oral cavity, was developed particularly for the restoration of posterior teeth. ${ }^{8}$

Flowable composites are generally produced with low viscosity. Since their filler content is low, their mechanical properties are slightly reduced. ${ }^{3,7}$

Polyacid modified composite resin, commonly known as compomer, was first developed in the early 1990s. It was introduced as a new class of restorative materials which combined the aesthetics of conventional composite resins and, the fluoride release and adhesion of glass ionomer cements. ${ }^{9}$

Resin modified glass ionomers (RMCl) are hybrids of glass ionomers and composite resins. It was developed as a result of efforts to improve the mechanical properties of glass ionomer cement (GIC). These efforts also aimed to reduce the curing time and vulnerability of GIC to moisture..$^{10-12}$ One of the most important physical properties of restorative materials contributing to their clinical success is surface hardness, which also sets the mechanical properties of restorative materials. ${ }^{13,14}$ Barcol hardness test is based on resistance to indentation. Barcol hardness tester includes a metal indenter with tension spring and a scale on which hardness can be directly read. The penetration depth of the sharp point is converted into Barcol values
15 Barcol surface hardness tester is preferred in studies thanks to its portability and direct reading of measurements. ${ }^{13}$

Dental erosion is the pathologic, chronic and localized loss of dental hard tissue as a result of wearing due to a chemical process without the involvement of bacteria. ${ }^{16-18}$ The exogenous factors contributing to dental erosion are excessive consumption of acidic fruit juice and acidic carbonated beverages. ${ }^{19,20}$ Studies showed that tooth-coloured restorative materials such as GIC, polyacid-modified composite resins and composite resins are also affected by dental erosion. ${ }^{21,22}$

The aim of this study was to examine the effects of different acidic beverages on the surface hardness of commonly used restorative materials.

\section{MATERIAL AND METHODS}

The brands, manufacturers and chemical composition of the materials used in this study are listed in Table 1.

\begin{tabular}{|c|c|c|c|c|c|}
\hline Material & Classification & Composition & Shape & Manufacturer & $\begin{array}{c}\text { Batch } \\
\text { Number }\end{array}$ \\
\hline $\begin{array}{c}\text { Filtek } \\
\text { Silorane }\end{array}$ & $\begin{array}{l}\text { Microhybrid } \\
\text { composite } \\
\text { resin }\end{array}$ & $\begin{array}{c}\text { Silorane based } \\
\text { hydrophobic resin } \\
\text { matrix } \\
\text { camphorquinone, } \\
\text { yttrium fluoride. } \\
\text { Filler weight } 76 \%\end{array}$ & A2 & $\begin{array}{c}\text { 3M/ESPE, } \\
\text { (St. Paul, } \\
\text { MN, } \\
\text { USA) }\end{array}$ & N361058 \\
\hline $\begin{array}{c}\text { Filtek } \\
\text { Z-550 }\end{array}$ & $\begin{array}{l}\text { Nanohybrid } \\
\text { composite } \\
\text { resin }\end{array}$ & $\begin{array}{c}\text { Bis-GMA, Bis- } \\
\text { EMA, TEGDMA, } \\
\text { UDMA. } \\
\text { Filler weight } \\
81,8 \%\end{array}$ & A2 & $\begin{array}{l}\text { 3M/ESPE, } \\
\text { (St. Paul, MN, } \\
\text { USA) }\end{array}$ & N316660 \\
\hline \begin{tabular}{c|} 
Filtek \\
Ultimate \\
flowable
\end{tabular} & $\begin{array}{l}\text { Flowable } \\
\text { composite } \\
\text { resin }\end{array}$ & $\begin{array}{c}\text { Bis-GMA, } \\
\text { TEGDMA. } \\
\text { Filler weight } 65 \%\end{array}$ & A2 & $\begin{array}{l}\text { 3M/ESPE, } \\
\text { (St. Paul, } \\
\text { MN, } \\
\text { USA) }\end{array}$ & N375701 \\
\hline $\begin{array}{c}\text { Dyract } \\
\text { Extra }\end{array}$ & $\begin{array}{l}\text { Polyacid- } \\
\text { modified } \\
\text { composite } \\
\text { resin } \\
\text { (compomer) }\end{array}$ & $\begin{array}{l}\text { UDMA resin/TCB } \\
\text { resin, Strontium- } \\
\text { alumino-sodium- } \\
\text { fluoro- silicate } \\
\text { glass, strontium } \\
\text { fluoride, } \\
\text { initiators/stabilizers }\end{array}$ & A2 & $\begin{array}{c}\text { DENTSPLY } \\
\text { (DeTrey, } \\
\text { Konstanz, } \\
\text { Germany) }\end{array}$ & 1104001712 \\
\hline $\begin{array}{c}\text { Fuji II } \\
\text { LC }\end{array}$ & $\begin{array}{c}\text { Resin- } \\
\text { modified } \\
\text { glass-ionomer } \\
\text { cement }\end{array}$ & $\begin{array}{c}\text { HEMA, } \\
\text { methacrylate, } \\
\text { tartaric and } \\
\text { polyacrylic acid, } \\
\text { fluoroalumino } \\
\text { silicate. } \\
\text { Filler weight } 58 \%\end{array}$ & A2 & $\begin{array}{c}\mathrm{GC} \\
\text { Corporation, } \\
\text { (Tokyo, Japan) }\end{array}$ & 1111021 \\
\hline
\end{tabular}

\section{Specimen preparation}

For each restorative material, 60 disc-shaped specimens were prepared using a plexiglass mould of eight $\mathrm{mm}$ diameter and two $\mathrm{mm}$ thickness (a total of 300 specimens). In order to ensure that specimens would have flat polymerized surfaces with no bubble formation after curing, the top and bottom surfaces were covered with a polyester matrix strip (ESR-P Universal strip) and a thin glass microscope slide (one $\mathrm{mm}$ thickness). Pressure was applied to extrude excess material.

The restoratives were light polymerized according to the manufacturers' cure times with LED light curing unit (Elipar FreeLight 2, standard mode; 3M ESPE, St. Paul, MN, USA). With each restorative material, the 60 specimens 
were randomly divided into six groups ( $\mathrm{n}=10$ per group) according to the six immersion solutions to be examined in this study (Table 2).

Table 2. Study Groups.

\begin{tabular}{|c|c|c|c|c|}
\hline Group & $\begin{array}{c}\text { Restorative } \\
\text { Material }\end{array}$ & $\begin{array}{l}\text { Number of } \\
\text { Samples (n) }\end{array}$ & Sub-Group & $\begin{array}{c}\text { Number } \\
\text { of } \\
\text { Samples } \\
\text { (n) }\end{array}$ \\
\hline Group 1 & $\begin{array}{c}\text { Filtek } \\
\text { Silorane }\end{array}$ & $n=60$ & $\begin{array}{l}\text { 11- Cola } \\
\text { 12- Sour } \\
\text { Cherry } \\
\text { 13- Apple } \\
\text { 14- Energy } \\
\text { Drink } \\
\text { 15- Orange } \\
\text { 16-Artificial } \\
\text { Saliva }\end{array}$ & $\begin{array}{l}\mathrm{n}=10 \\
\mathrm{n}=10 \\
\mathrm{n}=10 \\
\mathrm{n}=10 \\
\mathrm{n}=10 \\
\mathrm{n}=10\end{array}$ \\
\hline Group 2 & Filtek Z 550 & $\mathrm{n}=60$ & $\begin{array}{l}\text { 21-Cola } \\
\text { 22- Sour } \\
\text { Cherry } \\
\text { 23- Apple } \\
\text { 24- Energy } \\
\text { Drink } \\
\text { 25- Orange } \\
\text { 26-Artificial } \\
\text { Saliva }\end{array}$ & $\begin{array}{l}\mathrm{n}=10 \\
\mathrm{n}=10 \\
\mathrm{n}=10 \\
\mathrm{n}=10 \\
\mathrm{n}=10 \\
\mathrm{n}=10\end{array}$ \\
\hline Group 3 & $\begin{array}{c}\text { Filtek } \\
\text { Ultimate } \\
\text { Flowable }\end{array}$ & $\mathrm{n}=60$ & $\begin{array}{l}\text { 31- Cola } \\
\text { 32- Sour } \\
\text { Cherry } \\
\text { 33- Apple } \\
\text { 34- Energy } \\
\text { Drink } \\
\text { 35- Orange } \\
\text { 36-Artificial } \\
\text { Saliva }\end{array}$ & $\begin{array}{l}\mathrm{n}=10 \\
\mathrm{n}=10 \\
\mathrm{n}=10 \\
\mathrm{n}=10 \\
\mathrm{n}=10 \\
\mathrm{n}=10\end{array}$ \\
\hline Group 4 & Dyract Extra & $\mathrm{n}=60$ & $\begin{array}{l}\text { 41- Cola } \\
\text { 42- Sour } \\
\text { Cherry } \\
\text { 43-Apple } \\
\text { 44- Energy } \\
\text { Drink } \\
\text { 45- Orange } \\
\text { 46-Artifical } \\
\text { Saliva }\end{array}$ & $\begin{array}{l}n=10 \\
n=10 \\
n=10 \\
n=10 \\
n=10 \\
n=10\end{array}$ \\
\hline Group 5 & Fuji II LC & $\mathrm{n}=60$ & $\begin{array}{l}\text { 51- Cola } \\
\text { 52- Sour } \\
\text { Cherry } \\
\text { 53- Apple } \\
\text { 54- Energy } \\
\text { Drink } \\
\text { 55- Orange } \\
\text { 56-Artificial } \\
\text { Saliva }\end{array}$ & $\begin{array}{l}\mathrm{n}=10 \\
\mathrm{n}=10 \\
\mathrm{n}=10 \\
\mathrm{n}=10 \\
\mathrm{n}=10 \\
\mathrm{n}=10\end{array}$ \\
\hline
\end{tabular}

Afterwards, they were polished with 600-800-1000-1200grit silicon carbide paper, as Mathias . (2009) did in their studies. Immediately after polishing, lower surfaces of the specimens were marked with a pen. All specimens were stored in artificial saliva at $37^{\circ} \mathrm{C}$ for 24 hours for rehydratation and completion of the polymerization.

\section{Microhardness test}

The Barcol impressor consists of a sharp point with a tension spring which is pressed against the surface to be tested. The sharp point has a diamater of $1 \mathrm{~mm}$. The value read on the scale decreases as the impressor penetrates the surface. ${ }^{24}$ The samples to be tested with this method are placed at the sharp tip of the Barcol Impressor, which is designed to exert a constant load of $10 \mathrm{~kg}$. A uniform pressure is exerted on the sample until the scale on the impressor reaches the maximum limit. The scale produces a direct value between 0 and 100.25

After 24 hours, the specimens were rinsed with distilled water and blotted dry with a tissue paper before remeasurement. Surface hardness measurements were conducted with a Barcol surface hardness tester (Sheen, GYZJ 935, Barber Colman Company, U.K.) from three different points on the top surface of each specimen and, average values were calculated.

The surface hardness test was performed twice: Firstly, at the beginning of the study before the specimens were immersed into acidic beverages and secondly, after one month at the end of the study.

\section{Immersion solutions}

Ten specimens of each material were immersed in one of the six different solutions (artificial saliva, cola, orange juice, apple juice, energy drink, and sour cherry juice (Table 3).

Table 3. Compositions of acidic beverages and artificial saliva used in the study.

\begin{tabular}{|c|c|c|c|}
\hline $\begin{array}{c}\text { Immersion } \\
\text { media } \\
\text { (brand) }\end{array}$ & $\begin{array}{c}\text { Manufacture } \\
\mathbf{r}\end{array}$ & Composition & pH \\
\hline $\begin{array}{l}\text { Cola (Coca } \\
\text { Cola) }\end{array}$ & $\begin{array}{l}\text { Coca Cola } \\
\text { Comp. (USA) }\end{array}$ & $\begin{array}{l}\text { Water, sugar, carbondioxide, colouring } \\
\text { agent, cola extract, caffeine, acidity } \\
\text { regulator (phosphoric acid) }\end{array}$ & 2.14 \\
\hline $\begin{array}{l}\text { Sour cherry } \\
\text { juice } \\
\text { (Cappy) }\end{array}$ & $\begin{array}{l}\text { Coca Cola } \\
\text { Comp. (USA) }\end{array}$ & $\begin{array}{l}\text { Water, concentrated sour cherry juice (at } \\
\text { least } 35 \% \text { ), sugar (sucrose/glucose } \\
\text { syrup), acidity regulator (citric acid) }\end{array}$ & 2.86 \\
\hline $\begin{array}{l}\text { Apple juice } \\
\text { (Cappy) }\end{array}$ & $\begin{array}{l}\text { Coca Cola } \\
\text { Comp. (USA) }\end{array}$ & $\begin{array}{l}\text { Concentrated apple juice }(100 \%) \text {, water, } \\
\text { aroma, acidity regulator (citric acid) }\end{array}$ & 3.14 \\
\hline $\begin{array}{l}\text { Energy } \\
\text { drink } \\
\text { (RedBull) }\end{array}$ & $\begin{array}{c}\text { RedBull } \\
\text { Gmbh (USA) }\end{array}$ & $\begin{array}{l}\text { Water, sucrose, glucose, carbondioxide, } \\
\text { taurine, caffeine, inositol, } \\
\text { glucuronolactone, vitamins, acidity } \\
\text { regulator (sodium citrate) }\end{array}$ & 3.21 \\
\hline $\begin{array}{l}\text { Orange } \\
\text { juice } \\
\text { (Cappy) }\end{array}$ & $\begin{array}{l}\text { Coca Cola } \\
\text { Comp. (USA) }\end{array}$ & $\begin{array}{l}\text { Concentrated orange juice with real } \\
\text { orange pieces }(100 \%) \text { water, aroma }\end{array}$ & 3.60 \\
\hline $\begin{array}{l}\text { Artificial } \\
\text { saliva }\end{array}$ & $\begin{array}{c}\text { Ondokuz } \\
\text { Mayis } \\
\text { University, } \\
\text { Faculty of } \\
\text { Science and } \\
\text { Letters, } \\
\text { Department of } \\
\text { Chemistry }\end{array}$ & $\begin{array}{l}1.160 \mathrm{gr} / \mathrm{liter}(\mathrm{L}) \text { Sodium Chloride, } 0.600 \\
\mathrm{~g} / \mathrm{L} \text { Calcium Chloride, } 0.600 \mathrm{~g} / \mathrm{L} \\
\text { Potassium Phosphate, } 1.491 \mathrm{~g} / \mathrm{L} \\
\text { Potassium Chloride, } 0.050 \mathrm{~g} / \mathrm{L} \text { Sodium } \\
\text { Flouride, Trace Sodium Hydroxide to } \\
\text { maintain a pH value of } 7 .\end{array}$ & 7.0 \\
\hline
\end{tabular}

Artificial saliva served as a control solution. The specimens were kept immersed in artificial saliva at $37^{\circ} \mathrm{C}$ in the interval between cycles.

In this study, immersion media were replaced daily throughout the study in order to prevent $\mathrm{pH}$ changes, as did Cogulu et al ${ }^{14}$ in their studies. The study was planned assuming that individuals consumed these beverages on a daily basis, which was the same procedure adopted by Sarı et al ${ }^{26}$ The $\mathrm{pH}$ values were obtained by using a digital pH electrode (Multi-parameter analyzer, Consort C864, Belgium) which had been calibrated immediately prior to use. 
After baseline microhardness was recorded, each sample was first immersed in $32.5 \mathrm{ml}$ of acidic beverage for five seconds and then for another five seconds in artificial saliva. This cycle was repeated ten times daily for each subgroup for a month. The specimen soaking protocol was simulated from an individual drinking a can of soft drink (325 ml). Total soaking time was 100 seconds. After the soaking sequence was completed, the specimen was rinsed with distilled water, blotted dry and subjected to post-immersion microhardness testing. The same procedure was also followed by Wongkhantee et al. ${ }^{21}$

\section{Statistical analysis}

The "power and sample size" test conducted showed that the sample size was 10 when the confidence interval was $95 \%$ (Minitab 13.2 V.).

The data collected in the study were firstly subjected to normality and variance homogeneity tests. To confirm the normality of data distribution, Kolmogrov - Smirnov test was applied. On the other hand, Levene test was used for variance homogeneity. To detect the differences between the materials and liquids, two-way ANOVA test and Tukey multiple comparison test were used.

Paired sample t-test (t-test for dependent samples) was used to reveal the significance of differences between the first and second measurements.

\section{RESULTS}

A total of 300 samples were prepared for the study. The pre- and post-experimental surface hardness of the samples was measured with a Barcol surface hardness tester. Table 4 shows the results of the variance analyses conducted on the surface hardness values.

The statistical evaluation of the surface hardness values for Fuji II LC, Filtek Ultimate Flowable, Dyract Extra, Filtek Silorane and Filtek Z 550, which were included in the study, revealed a significant $(p<0.05)$ difference among the restorative materials. With regard to the differences among the restorative materials, Filtek Z 550 (96.44 \pm 0.13 ) had the highest hardness value, followed by Filtek Silorane (96.02 \pm 0.13$)$ and Dyract Extra (95.98 \pm 0.13$)$ respectively. Filtek Ultimate Flowable had a surface hardness of $94.68 \pm 0.13$. The lowest surface hardness value was measured for Fuji II LC (93.35 \pm 0.13$)$. The Tukey and Duncan multiple comparison tests indicated a significant difference among these values.

There were statistical differences among the restorative materials with respect to pre-experimental values and post-experimental values. The classification of the restorative materials with regard to their post-experimental surface hardness values put Filtek Silorane, Filtek Z 550 and Dyract Extra in the same group with the highest surface hardness values, followed by Filtek Ultimate Flowable. Fuji II LC had the lowest surface hardness value (Table 4).
Table 4. Pre- and post-experimental surface hardness values of the restorative materials and statistical relationships among them.

\begin{tabular}{|l|c|c|}
\hline Restorative Material & $\begin{array}{c}\text { Pre-experimental mean } \\
\text { values } \\
(\mathbf{X} \pm \text { Ss) }\end{array}$ & $\begin{array}{c}\text { Post-experimental mean } \\
\text { values } \\
(\mathbf{X} \pm \text { Ss) }\end{array}$ \\
\hline Filtek Silorane & $96.02 \pm 0.13 \mathrm{~A}$ & $94.76 \pm 0.14 \mathrm{a}$ \\
\hline Filtek Z 550 & $96.44 \pm 0.13 \mathrm{~A}$ & $94.90 \pm 0.14 \mathrm{a}$ \\
\hline $\begin{array}{l}\text { Filtek Ultimate } \\
\text { Flowable }\end{array}$ & $94.68 \pm 0.13 \mathrm{~B}$ & $93.78 \pm 0.14 \mathrm{~b}$ \\
\hline Dyract Extra & $95.98 \pm 0.13 \mathrm{~A}$ & $94.92 \pm 0.14 \mathrm{a}$ \\
\hline Fuji II LC & $93.35 \pm 0.13 \mathrm{C}$ & $92.32 \pm 0.14 \mathrm{c}$ \\
\hline
\end{tabular}

There is no statistical difference between the values represented with the same letter $(p<0.05)$

It was found out that Filtek Z 550 was the most affected restorative material of all. There was no statistically significant difference among the rest of the restorative materials $(p<0.05)$ (Table 5).

Table 5. The influence of the beverages on the restorative materials as indicated by the difference between pre- and post-experimental values.

\begin{tabular}{|l|c|}
\hline Restorative Material & Difference between pre- and post-experimental values \\
\hline Filtek Silorane & $1.26 \mathrm{ab}$ \\
\hline Filtek Z 550 & $1.55 \mathrm{a}$ \\
\hline $\begin{array}{l}\text { Filtek Ultimate } \\
\text { Flowable }\end{array}$ & $0.90 \mathrm{~b}$ \\
\hline Dyract Extra & $1.06 \mathrm{~b}$ \\
\hline Fuji II LC & $1.03 \mathrm{~b}$ \\
\hline
\end{tabular}

There is no statistical difference between the values represented with the same letter $(\mathrm{p}<0.05)$ The restorative materials used in the study were soaked in six different liquids. Of these, the lowest difference was produced by artificial saliva in terms of surface hardness compared with the other liquids. This difference was statistically significant $(p<0.05)$. As for the acidic beverages, there was no statistically significant difference $(p>0.05)$ (Table 6).

Table 6. The comparison of the effects of beverages on surface hardness of restorative materials.

\begin{tabular}{|l|c|}
\hline Storage Medium & Change in surface hardness of restorative material \\
\hline Artificial Saliva & $0.5292 \mathrm{~b}$ \\
\hline Orange Juice & $1.1632 \mathrm{a}$ \\
\hline Energy Drink & $1.2220 \mathrm{a}$ \\
\hline Cola & $1.2340 \mathrm{a}$ \\
\hline Apple Juice & $1.3570 \mathrm{a}$ \\
\hline Sour Cherry Juice & $1.4546 \mathrm{a}$ \\
\hline
\end{tabular}

There is no statistical difference between the values represented with the same letter $(\mathrm{p}<0.05)$

\section{DISCUSSION}

Many types of food and beverages affect both natural teeth and the restorative materials. Previous studies showed that filling materials, when exposed to low $\mathrm{pH}$ media, disintegrated from the resin materials and that matrix components deteriorated. Most of the soft drinks are acidic and their $\mathrm{pH}$ values are 3.0 or lower. This suggests that long and continuous sipping of acidic beverages results in an erosion on tooth enamel and resin material. ${ }^{17,27}$ The volume of an acidic beverage or a liquid taken into the mouth is much greater than that of the saliva in the mouth; thus, teeth are exposed to a mixture of saliva and 
acidic solution for a short time. This lasts for a while and then the erosive liquid is either swallowed or expectorated. Afterwards, the saliva flow cleanses or buffers the acids. Cycles of exposure to saliva are recommended for studies since this approach is the closest to clinical conditions. ${ }^{28}$

The use of saliva in this type of studies is a challenge because the composition of human saliva is complicated and varies by individual oral health. ${ }^{29}$ In this study, the same type of artificial saliva used by Francisconi ${ }^{30}$, Honorio $^{31}$ and De Oliveira ${ }^{32}$ was preferred in order to maintain a standard and ideal saliva medium.

It was reported that any food with a $\mathrm{pH}$ value lower than the critical 5.5 level might demineralize the hard tissues of the tooth. 16 In this study, citric and phosphoric acid containing beverages with $\mathrm{pH}$ values lower than 5.5 were used.

One of the most important physical properties of the restorative materials contributing to their clinical success is the surface hardness and it also sets the mechanical properties of the restorative material. It not only increases resistance against scratch and wear but also prevents the easy deformation of the restorative material by various forces, which play an important role in the clinical success. ${ }^{13,14}$

There are different types of surface hardness tests. The most common testing methods used in dentistry for measuring the surface hardness of the restorative materials are Brinell, Rockwell, Shore, Barcol, Knoop and Vickers. ${ }^{15,33}$

Barcol hardness tester $(\mathrm{BH})$ is commonly preferred in studies examining surface hardness due to portability and direct reading of measurements. ${ }^{34-36}$ Therefore, $\mathrm{BH}$ was used in this study, which was of choice in studies conducted by Bagis and Ertas ${ }^{37}$ and Arisu et a ${ }^{38}$ Previous studies revealed that properties of the filler particles in the matrix such as size, shape, distribution, and content per volume/weight of the filler particles affect the mechanical durability, hardness and flexibility of the composite resins. ${ }^{39-41}$

Similarly, in this study, we found that initial surface hardness value of Filtek Z 550, a nano-hybrid composite resin with the highest filling material ratio, was higher than that of Filtek Silorane, a micro-hybrid composite resin. It was followed by compomer, flowable composite and resin-modified glass ionomer (RMCI) respectively. These results are in compliance with those of Sarı et al. ${ }^{26}$

Gonulol et al ${ }^{42}$, using a standard led device, reported that composite resin had the highest surface hardness value, which was followed by RCMI and compomer. In this study, we found that the surface hardness of compomer and composite resin was statistically same.

In another study conducted by Wassell. ${ }^{43}$, surface hard- ness ranges of vikers $(\mathrm{VH})$ and $\mathrm{BH}$ were compared and it was revealed that the range of $\mathrm{VH}$ was wider compared to that of $\mathrm{BH}$. It was showed that $\mathrm{BH}$ was a reliable but not a sensitive device to compare composites with regard to surface hardness. In our study, the ranges of surface hardness values were close to each other.

Cogulu. ${ }^{14}$ used compomer, $\mathrm{RMCl}$ and $\mathrm{GIC}$ as restorative materials in a similar study. They found that the effects of three different acidic beverages were similar when they evaluated the restorative materials according to the types of beverages. In this study, we found that five different types of acidic beverages had statistically similar effects on the same type of restorative material with respect to surface hardness. We believe that this results from the fact that $\mathrm{pH}$ values of the beverages evaluated were close to each other. This complies with the results of Cogulu et al. ${ }^{14}$

Ilie et al. ${ }^{44}$ found that silorane-based composite resin had significantly lower water absorption and solubility values compared to methacrylate-based composites (MBCs) due to its hydrophobic siloxane structure. They also found that it was quite resistant against wear when stored under conditions simulating oral conditions. In this study, we also observed that the decrease in the surface hardness of Filtek Silorane was lower compared to Filtek Z 550, which is an MBCs.

Rios et al ${ }^{45}$ used $\mathrm{GIC}, \mathrm{RMCl}$, composite resin and amalgam in their study on the subject. They soaked these restorative materials in cola for seven days with three cycles lasting five minutes each day. They reported that GIC had the highest values for wear and surface hardness decrease and that composite resin did not have the lowest values for wear and surface hardness change, which was a different finding compared to other studies. They suggested that this resulted from the short experiment period. In this study, we found that composite resin had a higher decrease in surface hardness compared to RMCl. However, this difference was not statistically significant. Honorio et a ${ }^{31}$ conducted a similar study using the same GIC, RMCl, composite resin and amalgam as Rios. ${ }^{45}$ Their study lasted 35 days and the lowest difference was observed in the restorative material with the highest surface hardness value.

Another study by Bors et al ${ }^{46}$ involved two composite resins (Filtek Z 550, X-tra fill), two compomers (Dyrac Extra, twinky star) and two glass ionomers ( Ketac molar- Fuji II LC) as restorative materials. The samples were soaked in Coca Cola for 30 days with five cycles lasting five minutes each day. The erosive wear of the samples were measured, based on the difference between surface roughness measured at the beginning and the end of the study. It was reported that composite restorative material had a higher erosive wear compared to compomer. This result 
was attributed to the short experiment period and exposure to cycles.

Badra et al. ${ }^{47}$ reported that there were several effects on the microhardness and surface roughness of the restorative materials which resulted from the characteristics of the materials, the type of beverage and the evaluation period. They also reported that when the immersion period prolonged, the effects on the properties of the resins were more prominent.

\section{CONCLUSION}

1. With the increasing consumption of acidic beverages by the young population in recent years, dental erosion has become an important health issue. We observed that acidic beverages affected the surface hardness of restorative materials used in our study.

2. In our study, all restorative materials, except for Filtek Z 550, underwent statistically similar changes in surface hardness values, which resulted from short study period (a total of 50 minutes of contact with the acidic beverage) and exposure to artificial saliva-beverage cycle.

3. These results show that beverages with erosive potentials affect the surface hardness of restorative materials used in this study. We believe that such studies need to be supported by in vivo studies and that longer storage periods may produce higher statistical differences.

\section{REFERENCES}

1. Toz Akalin T. Kusdemir M. Gozukara Bag H. Clinical evaluation of 107 anterior teeth restored with direct nanofilled resin composite: up to 32 months. Yeditepe J Dent 2016; 12: 21-28.

2. Luiz BKM, . Effect of drinks on the surface properties of dental composites. Polym Test 2007; 26: 855-861.

3. Ferracane JL. Resin composite-State of the art. Dent Mater 2011; 27: 29-38.

4. Sakaguchi RL, Mitra SB. Restorative materials-Composites and polymers. In: Sakaguchi RL, Powers JM, editors. Craig's restorative dental materials. 13th. United States, Mosby Inc. 2012; 9: 160-198.

5. Ertas E, Guler AU, Yucel AC, Koprulu H, Guler E. Color stability of resin composites after immersion in different drinks. Dent Mater J 2006; 25: 371-376.

6. Baltacioglu IH. A comparison of nanohybrid containing composites with regard to micro leakage with different curing lights. Ankara University, Institute of Health Sciences, Ankara, Doctorate thesis, 2011; 3-30.

7. Dayangac BG. Kompozit rezinler. In: Kompozit Restorasyonlar. 2. baskı, İstanbul, Quintessence 2011a; 1: 1-25. 8. Yikilgan I, Gurel MA, Bala O, Omurlu H. A comparison of the water absorption and solubility of different aesthetic restorative materials. J Dent Gazi Univ 2010; 27: 93-98.

9. Nicholson JW. Polyacid-modified composite resins "compomers" and their use in clinical dentistry. Dent Mater 2007; 23: 615-622.

10. Hse KMY, Leung SK, Wei SHY. Resin-ionomer restorative materials for children: A review. Aust Dent J 1999; 44:1-11.

11. Moore KB, Avery DR. Dental materials. In: McDonald RE, Avery DR, Dean JA, editors. Dentistry for the child and adolescent. 8th. USA, Mosby. 2004; 16: 333-352.

12. Berzins DW, Abey $S$, Costache MC, Wilkie CA, Roberts HW. Resin modified glass-ionomer setting reaction competition. J Dent Res 2010; 89:82-86.

13. Deliktas D, Ulusoy N. The effects of different curing lights on the surface hardness of hybrid and nanohybrid composit resins. AU Dishek Fak Derg 2006; 31: 1-10.

14. Cogulu D, Ersin N, Topaloglu-Ak A. An evaluation of the effect of acidic beverages on the surface hardness of three different restorative materials. Dicle Dishek Derg 2008; 9: 7-12.

15. Anusavice KJ. Mechanical properties of dental materials. In: Anusavice KJ, Shen C, Rawls $\mathrm{RH}$, editors. Phillips' science of dental materials. 12th. China, Elsevier Saunders. 2012; 4: 48-68.

16. Grippo JO, Simring M. Dental erosion revisited. JADA 1995; 126: 619-630.

17. Lussi A, Jaeggi T, Zero D. The role of diet in aetiology of dental erosion. Caries Res 2004; 38: 34-44.

18. Edeer D, Martin CW. Occupational dental erosion. 1st Ed., Richmond BC: WorksafeBc Evidence Based Practice Group, 2010. p. 1-30.

19. Zero DT. Etiology of dental erosion extrinsic factors. Eur J Oral Sci 1996; 104: 162-177.

20. Zero DT, Lussi A. Behavioral Factors. Monogr Oral Sci 2006; 20: 100-105.

21. Wongkhantee S, Patanapiradej V, Maneenut C, Tantbirojn D. Effect of acidic food and drinks on surface hardness of enamel, dentine, and tooth coloured filling materials. J Dent 2006; 34: 214-220.

22. Yu H, Wegehaupt FJ, Wiegand A, Roos M, Atin T. Erosion and abrasion of tooth-colored restorative materials and human enamel. J Dent 2009; 37: 913-922.

23. Mathias $P$, Lessa AG, Cavalcanti AN. Effect of erosive and abrasive challenges on the bond strength and marginal degradation of composite restorations. Rev odonto ciênc. 2009; 24: 290-294.

24. Braga RR, Pfeifer CS, Sakagucci RL. Testing of dental materials and biomechanics. In: Sakaguchi RL, Powers JM, editors. Craig's restorative dental materials. 13th., United States, Mosby Inc. 2012; 5: 83-107.

25. Deliktas D. The effects of several liquids on the surface hardness of two composite resins polymerized with different curing lights. Ankara University, Institute of Health Sciences, Ankara, Doctorate thesis, 2006; 18, 84.

26. Sari ME, Koyuturk AE, Cankaya S. Effects of surface 
hardness and surface roughness of restorative materials and enamel of daily consumed food and beverages. $J$ Dent Ataturk Univ 2010; 20: 153-161.

27. Han L, Okamoto A, Fukushima M, Okiji T. Evalution of flowable resin composite surfaces eroded by acidic and alcoholic drinks. Dent Mater J 2008; 27: 455-465.

28. Young A, Tenuta LMA. Initial erosion models. Caries Res 2011; 45: 33-42.

29. Mckenzie MA, Linden RWA, Nicholson JW. The Physical properties of conventional and resin modified glass ionomer dental dements stored in saliva, proprietary acidic beverages, saline and water. Biomaterials 2003; 24: 4063-4069.

30. Francisconi LF, . Effect of erosive pH cycling on different restorative materials and on enamel restored with these materials. Oper Dent 2008; 33: 203-208.

31. Honorio HM, Rios $D$, Francisconi LF, Magalhaes AC, Machado MAAM, Buzalaf MAR. Effect of prolonged erosive $\mathrm{pH}$ cycling on different restorative materials. $\mathrm{J}$ Oral Rehabil 2008; 35: 947-953.

32. De Oliveira, Garcia PPNS, Dos Santos PA, Campos JADB. Surface roughness and hardness of a composite resin: Influence of finishing and polishing and immersion methods. J Mater Res 2010; 13: 409-415.

33. Shahdad AS, McCabe JF, Bull S, Rusby S, Wassell WR. Hardness measured with traditional vickers and martens methods. Dent Mater 2007; 23: 1079-1085.

34. Abate PF, Zahra VN, Macchi RL. Effect of photopolymerization variables on composite hardness. J Prosthet Dent 2001; 86: 632-635.

35. Mills RW, Uhl A, Blackwell GB, Jandt KD. High power light emitting diode (LED) arrays versus halogen light polymerization of oral biomaterials: Barcol hardness, compressive strength and radiometric properties. Biomaterials 2002; 23: 2955-2963.

36. Kauppi MR, Combe EC. Polymerization of orthodontic adhesives using modern high-intensity visible curing lights. Am J Orthod Dentofacial Orthop 2003; 124: 316322.

37. Bagis $\mathrm{YH}$, Ertas E. Effects of storage conditions on surface hardness of composite resin: in vitro $\mathrm{T}$ Klin $\mathrm{J}$ Dental Sci 2000; 6: 41-47.

38. Arisu HD, Bala O, Uctasli MB. Barcoll hardness of different restorative materials cured by halogen or led. $J$ Dent Gazi Univ 2008; 25: 19-24.

39. Agbaje LO, Shaba OP, Adegbulugbe IC. Evaluation of the mechanical and physical properties of a posterior resin composite in posterior adult teeth. Niger J Clin Pract 2010; 13: 431-435.

40. D'Alpino PHP, . Methacrylate-and silorane-based composite restorations: Hardness, depth of cure and interfacial gap formation as a function of the energy dose. Dent Mater 2011; 27: 1162-1169.
41. Bechtold J, Dos-Santos PJ, Anido-Anido A, Di Hipolito V, Alonso RCB, D'Alpino PHP. Hardness, polymerization depth, and internal adaptation of Class II silorane composite restorations as a function of polymerization protocol. Eur J Dent 2012; 6: 133-140.

42. Gonulol N, Ozer S, Tunc ES. Effect of a third-generation LED LCU on microhardness of tooth-colored restorative materials. Int J Paediatr Dent 2016; 26: 376-382.

43. Wassell RW, McCabe JF, Walls AW. Subsurface deformation associated with hardness measurements of composites. Dent Mater 1992; 8: 218-223.

44. Ilie N, Rencz A, Hickel R. Investigations towards nano-hybrid resin-based composites. Clin Oral Invest 2013; 17: 185- 193.

45. Rios D, Honorio HM, Francisconi LF, Magalhaes AC, De Andrade Moreira Machado MA, Buzalaf MAR. In situ effect of an erosive challenge on different restorative materials and on enamel adjacent to these materials. J Dent 2008; 36: 152- 157.

46. Bors A, Molnar-Varlam C, Székely M. The behaviour of composites, glass ionomers and compomers in erosive conditions - in vitro study. Acta Medica Marisiensis 2014; 60: 200203

47. Badra VV, Faraoni JJ, Ramos RP, Palma-Dibb RG. Influence of different beverages on the microhardness and surface roughness of resin composites. Oper Dent 2005; 30: 213-219. 
